Vol.: 5 Issue: 2 Date: 31.12.2021 Received: 20.10.2021 Accepted: 16.12.2021 Final Version: 31.12.2021

ISVOS Journal, 2021, 5(2): 218-229 - https://doi.org/10.47897/bilmes.1035948

\title{
The Effect Of The Covid-19 Pandemic On Health Services (Evaluation of Health Statistics of OECD Countries)
}

\author{
Altuğ ÇAĞATAY ${ }^{\mathrm{a},}$, Ümit ARSLAN $^{\mathrm{b}-1}$, Seda YILMAZ ${ }^{\mathrm{c}}$ \\ ${ }^{a}$ Tokat Gaziosmanpaşa University, Almus Vocational School, Tokat, Turkey

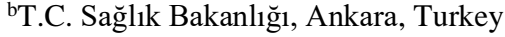 \\ ${ }^{\mathrm{c}}$ Tokat Gaziosmanpaşa University, Graduate Education Institute, Tokat, Turkey \\ ORCID ID:0000-0001-7067-5570 \\ ORCID ID: 0000-0002-9781-3723 \\ ORCID ID: 0000-0002-5478-3595
}

\begin{abstract}
In this study, it is aimed to compare the health statistics of OECD countries in terms of Covid-19 and general health statistics. Quantitative screening method was used in the study and health statistics of OECD 2020, 2021, World Health Organization Covid-19 statistics and Ministry of Health 2019 health statistics were used. According to the number of Covid-19 cases reported among OECD countries, the high death rate is in Hungary with 3.083 per hundred thousand, Italy with 2.610 per hundred thousand, Colombia with 2,533 per hundred thousand, Chile with 2.170 per hundred thousand and 1.920 per hundred thousand. It is in Greece. The lowest death rates are in Norway with 378 per hundred thousand, Denmark (558), Israel (609), Finland (706), Netherlands (711) and Turkey with 873 per hundred thousand. The lowest deaths by population occurred in South Korea (\%o 0.08), Australia (\% 0.08) and Japan (\%o 0.15). Turkey is among the countries where the number of deaths from Covid-19 is low (\% 0.94) according to the population. The countries with the highest rate of intensive care beds are Czechia, Turkey and Estonia. The average length of stay in hospital was highest in South Korea (18 days), Japan (16 days), and Hungary (9.6 days). The minimum length of stay in hospital is in Turkey (4.2 days), Mexico (4.4 days) and the Netherlands (5.2 days). In general, when we look at the health statistics of our country, we can say that it is in better condition than other OECD countries. However, the number of health personnel needs to be increased. When compared with the Covid-19 data (death rates, bed occupancy rates, etc.), it is seen that our country is successful in the fight against Covid19. It is thought that this result depends on the strength of the health infrastructure. With the increase in vaccination, it is expected that deaths due to Covid-19 will decrease even more all over the world.
\end{abstract}

Keywords: "Covid-19, Health Services, OECD country Statistics"

\section{Giriş}

Covid-19 ile birlikte bazı devletler etkili önlemlerle salgını sınırları içerisinde kontrol edebiliyorken, bazıları da bu alanda başarısız olmuştur. Pandemi ilerledikçe, hükümetler sağlık, imalat, ithalat, ticaret ve turizm gibi sektörlerde salgının etkilerini hissetmeye başlamış ve bu etkilerden korunmak ya da krizi firsata dönüştürebilmek için birçok alanda değişik yönelimler göstermişlerdir (Yorulmaz vd., 2021: 164).

Covid-19 süreci ile dünyayı hızlı bir şekilde etkileyen salgınların idare edilmesinde DSÖ gibi global ya da çok uluslu kuruluşların kuvvetlendirilmesinin önemi ve sağlığın sadece sağlık sektörünün işi olmadığı anlaşılmıştır (Gölbaşı ve Metintaş, 2020: 204).

Pandemi süresince hükümetler vatandaşlarını kriz durumlarında beraber hareket etmeli ve bilimsel kuruluşlar da halk için kanıta dayalı güvenilir kaynaklar haline gelen yayın organları oluşturulmalıdır (Timmis ve Brüssow, 2020: 1989). Aş1lamayı yaşanılan ülke, aile, toplum, sağlık çalışanları vb. pek çok etmen etkilediği için karşılıklı diyaloglarla toplum geneline yayarak aşılanmanın geliştirilmesi ve devamının gerçekleştirilmesi gerekmektedir (Erkekoğlu vd., 2020: 213). Ayrıca nüfuslar önümüzdeki aylarda kademeli olarak aşılandıkça, politika yapıcılar aşılananlar ile aşılanmayanlar arasında bir ayrım yaratma riskine ve bunun eşitsizliği daha da kötüleştirme üzerindeki etkisine karşı dikkatli olmalıdır (Gooch, 2020). Öncelikle sağlık hizmetlerinin yeniden düzenlenmesi gerektiği çok iyi anlaşılmıştır. Aile hekimliği sistemi ve merkezlerinin altyapısı ve fiziki alanı güçlendirilmeli, ilgili nüfusa dayalı iyileştirmeler yapılmalı ve hastanelere kabulün kontrol edilmesi için hastanelere sevk sistemi uygulanmalıdır. Öte yandan kronik hastalıkların takibi, evde bakım hizmetleri, evde yaşlı bakımı hizmetleri ve sağlık eğitimi hizmetleri, çevrimiçi

\footnotetext{
${ }^{1}$ Sorumlu Yazar. Tel.: 05054894054
}

E-posta adresi: umitars@ hotmail.com 
sistemler ve teletıp hizmetlerinin ülke genelinde yaygınlaştırılması gerekmektedir. Sağlık çalışanları ve bireylerin teması en aza indirilmeli, etkin ve hızlı bir şekilde yürütülmelidir (Tengilimoğlu vd.,2021: 7).

Dünya Sağlık Örgütü'ne (WHO) göre, bugüne kadar ki şüpheli vakalar için hem epidemiyolojik ve klinik kriterler bulunmaktadır (Galván-Tejada, 2020: 1). Hastalığın öncelikle sosyal aktivite düzeyine bağlı olan etkileşimler, sosyal ortamlar ile buluşma, restoranlarda yemek yemek, perakende mağazalarda alışveriş yapmak ve seyahat etmek gibi sebeplerle bulaştığı gözlemlenmiştir (Farboodi vd., 2020: 1). Covid-19'un klinik özellikleri belirlenmiş olup çoğu insan hafif semptomlar gösterir veya hiç göstermez iken ölümler esas olarak yaşlılarda ve kronik hastalığı olan hastalarda meydana gelmektedir (Watkins, 2020: 2).

\subsection{Literatür Araştırması}

\section{Türkiye Covid-19 Pandemi Süreci}

Türkiye de diğer ülkelerde olduğu gibi pandemiden ciddi şekilde etkilenmiş ve etkilenmeye devam etmektedir. Filyasyon çalışmaları, sosyal izolasyon, kişisel koruyucu ekipman kullanımları Türkiye'nin Covid-19 pandemisindeki sağlık politikasını oluşturmaktadır (Eser vd., 2021: 32). Türkiye'de 11 Mart 2020 tarihinden bu yana bütün kamu ve özel hastaneleri, pandemi hastaneleri olarak deklare edilmiş ayrıca Covid-19'a enfekte olan bütün bireyler için ihtiyaç duyulan tıbbi tedaviler de ücretsiz olmuştur (Erol, 2020: 148). 2 Nisan 2020 tarihinde “Aşı ve İlaç Geliştirme Sanal Konferansı” gerçekleştirilmiş olup Türkiye Sanayi ve Teknoloji Bakanı konferansın açılış konuşmasında; Covid-19 Platformu kapsamında hem kimyasal hem de biyoteknolojik yöntemlerin uygulanacağı yedi farklı aşı ve 7 farklı ilaç geliştirme projesinin mevcudiyetinden bahsetmiştir (Akarsu vd., 2021: 2).

\section{OECD Ülkeleri ve Pandemi Süreci}

Salgın ile mücadeleyi birçok yönden incelemek gerekmektedir. Çünkü salgınlar bireylerin sağlık sistemlerine doğrudan müdahalesiyle birlikte, yaşanılan doğal ve sosyal çevreyi de etkilemektedir (Eroğlu, 2020:565). Şu anda yaşadığımız mevcut pandemi, birçok ülkede sağlık sisteminin zayıf noktalarını göstermiştir. Tesisat kapasitesi, sağlık çalışanlarının dağılımı, ekipman ve malzeme sorunları yaşanan sağlık sistemlerine yeni bakış açıları getirmiştir. Bulaşma riski nedeniyle hastaneye kabulün ertelenmesi, sokağa çıkma yasağı, poliklinik başvuru sayısının azaltılması gibi durumlar göz önüne alındığında, hastanelerde sağlık hizmeti talebinin artması kaçınılmazdır ve sağlık çalışanlarının normal şartlarda çalışması beklenirdi. hızlı bir oran. Riski en aza indirmek için iş gücü planlarının önceden hazırlanması ve zorunlu sevk zincirinin sağlık hizmetlerine dahil edilmesi önerilebilir. Sevk zinciri aile hekimliği sisteminin ayrılmaz bir parçası olduğu için bireylerde davranış değişikliği avantajlı bir duruma dönüştürülebilir (Tengilimoğlu vd.,2021: 7). Covid-19 ile birlikte bazı devletler etkili önlemlerle salgını sınırları içerisinde kontrol edebiliyorken, bazıları da bu alanda başarısız olmuştur. Bu devletlerde salgının bırakacağı siyasal, toplumsal ve iktisadi etkilerin neler olabileceği konusunda tartışmalar devam etmektedir (İmga ve Ayhan, 2020:7). Pandemi ilerledikçe, hükümetler sağlık, imalat, ithalat, ticaret ve turizm gibi sektörlerde salgının etkilerini hissetmeye başlamış ve bu etkilerden korunmak ya da krizi firsata dönüştürebilmek için birçok alanda değişik yönelimler göstermişlerdir (Yorulmaz vd., 2021: 164). Covid-19 ile birlikte ortaya çıkan bir diğer önemli sonuç ise; ekonomik, sosyal ve askeri imkânlara sahip olma açısından dünyanın en güçlüleri arasında yer alan ülkelerin, herhangi bir salgın karşısında güçlerinin ne kadar kırılgan olduğu gerçeği olmuştur. Özellikle sağlık temelli yapılan araştırmalara göre; sağlık sistemlerine çokça güvenen ve bundan dolayı iyi performans sergilemesi beklenen birçok ülkenin (İngiltere, Amerika, İtalya, ispanya vb.), bu pandemi ile birlikte mevcut sağlık sistemlerinin ne kadar güvenilir olduğu da sorgulanır hale gelmiştir. Muhtemeldir ki pandemi sonrası süreçte, dünya üzerindeki bütün ülkeler, sağlık sistemlerini yeniden tasarlamak ve planlamalarını, bu süreçteki tecrübelerine dayandırarak yenilemek zorunda kalacaktır Budak ve Korkmaz, 2020:75).

OECD ülkeleri Covid-19 pandemisine karşı yetersiz kalmaktadır. Bunun sebepleri arasında 1. basamak sağlık hizmetlerinin hastaları zamanında teşhis edememesi sebebiyle enfekte olan hastaların çok fazla talepte bulunması, virüse karşı koruma sağlayan maske ve önlüğün sınırlı olması, nüfusa karşı hastane yoğun bakım ve hasta yataklarının kısıtlı olması yer almaktadır (Yiğit, 2020: 411). Yapılan araştırmalar genel popülasyonda yüksek oranda maske kullanımının virüs bulaşmasını ve SARS-COV-2 damlacıklarının havada asılı kalması nedeniyle yayılımını azaltabileceğini göstermektedir (Yan vd., 2021: 2). Ek olarak, toplumda maske kullanımı, ancak çoğu insan maske takarsa etkili üreme sayısında anlamlı bir azalma sağlayacaktır (Cheng vd., 2020: 2). Amerika' da yapılan bir araştırmaya göre kolektivist kültürlerin karşılıklı bağımlılığa ve ortak hedeflere vurgusu nedeniyle, bu tür kültürlerdeki birçok insan maske takmayı yalnızca bir sorumluluk olarak değil, aynı zamanda pandemi ile mücadelede bir dayanışma sembolü olarak görmektedir (Lu, Jin, \& English, 2021:1).Ülkeler de maske kullanımına ilişkin yönergeler açıklamış olup Virüsün yayılmasını en aza indirmek için vatandaşlarının halka açık alanlarda maske takmasını zorunlu tutmaktadır. Bu nedenle, halka açık alanlarda maske takmak, virüsün yayılmasını durdurmanın en etkili yollarından biri olarak görülmektedir (Rab vd., 2020: 1617).

İngiltere pandemi ile mücadelede en geç harekete geçen ülkelerin başındadır. Salgının ilk dönemlerinde "sürü bağışıklığı" stratejisini benimseyen İngiltere'de vakaların ve ölüm sayılarının giderek artış göstermesi hükümeti önlemler almaya sevk etmiştir (Munis ve Aydın, 2021: 70). Buna karşılık olarak Almanya pandemi süresince İtalya ve İspanya'dan sonra Avrupa'da en çok vakanın görüldüğü ülkeler arasındadır. Ancak hayatını kaybeden hastaların sayısının diğer ülkelere kıyasla çok daha düşük olması tüm dünyada dikkatleri Almanya'nın izlediği politikaya ve aldığı önlemlere çevirmiştir. Bunun cevabını hükümet danışmanı 
Christian Drosten, "Bizde ölüm oranı çok düşük çünkü biz oldukça fazla oranda laboratuvar testi yöntemi uyguluyoruz." şeklinde cevap vermiştir (Keskin, 2020). Covid-19 pandemisi yıkımını artırırken, dünyanın dört bir yanındaki doktorlar, hayat kurtaran kaynaklarını paylaştırma gibi göz korkutucu bir görevle karşı karşıyadır. Acil servislerde veya yoğun bakım ünitelerinde "ilk gelen ilk hizmet alır" yöntemi uygulanamamaktadır. Ayrıca İtalya'da doktorlar vantilatörleri 60 yaşın altındakilerle sınırladığını bildirmiştir (Iserson, 2020:5).

Covid 19 pandemi sürecinden en fazla etkilenen ülkelerin başında ABD gelmektedir. Sağlık hizmetlerini özel sektör tarafından karşılayan ABD vatandaşları, bireysel sağlık sigortaları olmadığı takdirde acil servis harici bir hizmet alamamaktadır. ABD hastaneleri kar amacı güden hastaneler olması sebebiyle bu süreçte yoğun hizmet vermesine karşılık yeterli düzeyde kar elde edemediği için büyük sıkıntılar yaşamaktadır. Kısaca ABD'de sağlık teknoloji altyapısı gelişmiş olmasına rağmen, toplum içindeki dağılımı başka gelişmiş ülkelerdeki birçok ulusal sağlık sisteminin oldukça gerisinde kalmaktadır (Yıldızoğlu, 2020).

Amerika Birleşik Devletleri’nde yapılan ve 30.529 kişinin katıldığ bir çalışmada katılımcıların en yaygın olarak gösterdiği semptomlar; baş ağrısı, titreme veya terleme, nefes almada zorluk, tat ve koku almada azalma ve öksürük olarak tespit edilmiştir (Quer, 2021: 75). Yine bir İtalyan çalışmasında taburcu olduktan 7 hafta sonra 143 birey izlenmiş ve \%53'ünün yorgunluk, \%43'ünün nefes darlığı ve \%27'sinin eklem ağrısı bildirdiği belirlenmiştir (Halpin vd., 2021: 1014). Birleşik Krallık ve ABD’de yoğun bakım ünitelerinden elde edilen verilerde gözlemlenen demografik eğilim ise, ölen bireyler daha fazla oranda Siyah, Asyalı ve Azınlık Etnik hastalardır (Chakravorty vd., 2020: 2). Biyolojik risk faktörlerinden şeker hastalığı ve akciğer hastalığı gibi tıbbi risk faktörlerine, sosyoekonomik durum, kalabalık hane halkı ve toplu taşıma kullanımı gibi sosyal risk faktörlerine kadar sayısız faktör öne sürülmüştür (Karmakar vd., 2021: 2).

Bir diğer yandan enfeksiyon riski en yüksek olanlar, enfekte olan bireyler ile temas halinde olanlardır, yani ön saflardaki doktorlar ve hemşireler olmak üzere sağlık çalışanlarıdır. Yükssek stresli bir çalışma ortamı, sağlık çalışanlarının bağışıklığını daha da zayıflatmış ve hastalara uzun süre maruz kalınması, enfeksiyon riskini hızla artırmıştır (Du vd., 2021: 4).İşyerleri ve bireyler Covid-19 için subklinik ve asemptomatik taşıyıcılar olarak potansiyel bir enfeksiyon kaynağıdır ve bu durum hastanelerde sağlık personelleri için önemli bir tehdit oluşturmaktadır (Kumar vd., 2021: 2). Bununla birlikte, sağlık çalışanları sağlık çalışanları olmayanlara göre daha erken bakım alabilmekte, bu da tanı, hastaneye yatış ve hayatta kalma oranlarını diğer bireylere karşı daha fazla etkileyebilmektedir (Shepard vd., 2021: 545).

Mevcut tahminlere göre, gelişmiş ekonomilerdeki yetişkin nüfusun büyük bölümü 2022'nin ortalarında aş1lanmış olacak, orta gelirli ülkeler için ise 2022'nin sonlarına ya da 2023'ün başlarına kadar uzayabilirken, daha yoksul ülkeler için toplu bağışıklama 2024'e kadar uzayacaktır (Elgar vd., 2021: 2). Canlı atenüe, inaktif, mRNA ve DNA içeren ve vektör aşılar olmak üzere dört çeşit aşı tipi bulunmaktadır. Farklı gelişmiş aşı teknolojileri, Covid-19'u önlemedeki potansiyellerini zaten göstermiştir ve mRNA ve adenoviral vektör aşıları da dahil olmak üzere bu tür birkaç aşı, klinik deneyleri başarıyla tamamladıktan sonra dünya çapında kullanım için yetkilendirilmiştir (Kozlovskaya vd., 2021: 1791).

Mevcut aşıların varlığı, yeni enfeksiyonları en aza indirmek için kilit unsur olduğundan insanları ve özellikle sağlık çalışanlarını aşılamak çok önemlidir (Troiano ve Nardi, 2021: 246). Bunun yanı sıra bulaşıcı bir hastalığa maruz kalmak kişiyi riske attı̆̆ından ve aşılanmazlarsa bireylerin hastalığı başkalarına bulaştırma olasılıkları çok daha yüksek olduğundan, aşı tereddütü hem birey hem de toplum için tehlike arz etmektedir (Coustasse vd., 2020: 72). Luyten ve arkadaşları tarafından 1402 İngiliz vatandaşına yapılan aşı tereddüdü araştırmasında katılımcıların \%90'ında en az bir boyutta aşı tereddüdü bulunduğu ve bu tereddüdün aşılar ile ilgili risk algısından kaynaklandığı tespit edilmiştir (Yalçın-Balçık ve Demir, 2021: 379). Büyük ölçüde yüksek gelirli ülkelerde yürütülen yayınlanmış araştırmalar, tereddütün başlıca nedenlerinden biri olarak, aşı geliştirme sürecinin hızlı temposu da dahil olmak üzere, Covid-19'a karşı aşıların güvenliğine ilişkin endişelerini belirtmektedir (Machingaidze ve Wiysonge, 2021: 1338).

\section{Analiz}

\subsection{Gereç ve Yöntem}

Çalışmada OECD ülkelerinin sağlık istatistikleri Covid-19 ve genel sağlık istatistikleri yönünden karşılaştırılmış ve yorumlanmıştır.

\subsection{Bulgular}

OECD 2020,2021 yılı sağlık istatistiklerinden, Dünya Sağlık Örgütü Covid-19 istatistiklerinden ve Sağlık Bakanlığı 2019 yılı sağlık istatistiklerinden yararlanılarak aşağıdaki veriler oluşturulmuştur. Bulgular, OECD ülkelerinin Covid-19 istatistikleri, Covid-19 aşı uygulama durumları, yatak kapasiteleri, ortalama yatış süreleri, personel sayıları ve sağlık harcamaları yönünden başlıklar halinde incelenmiştir.

\subsubsection{OECD ülkelerinin Covid-19 Verilerinin Karşılaştırılması}

Sağlıkta hizmetlerinde istatistik; kurum kaynaklarının daha aktif bir grafikte yönetilebilmesi, ülkeler ve sağlık hizmetleri sunucularının faaliyetlerini gerçekleştirirken ya da geleceğe yönelik karar verme aşamalarında yol gösterici olması, sağlık personeli 
ve sağlık kuruluşlarının takip edilmesi, güvenilir ve güncel verilere ulaşılabilme ve ulaşılan verilerin veri kaynağından alınması bakımından önemli katkılar sağlamaktadır. Böylece bu veriler veri işleme ile bir dizi analiz süreci sonucunda amaçlanan araştırma konusu üzerinde daha hızlı ve doğru karar verme imkanı sağlamaktadır. Bu nedenle çalışmanın daha iyi anlaşılabilmesi için OECD ülkelerinin sağlık hizmeti performansları ve Covid-19 pandemi dönemine ait bazı istatistikler aşağıda verilmektedir.

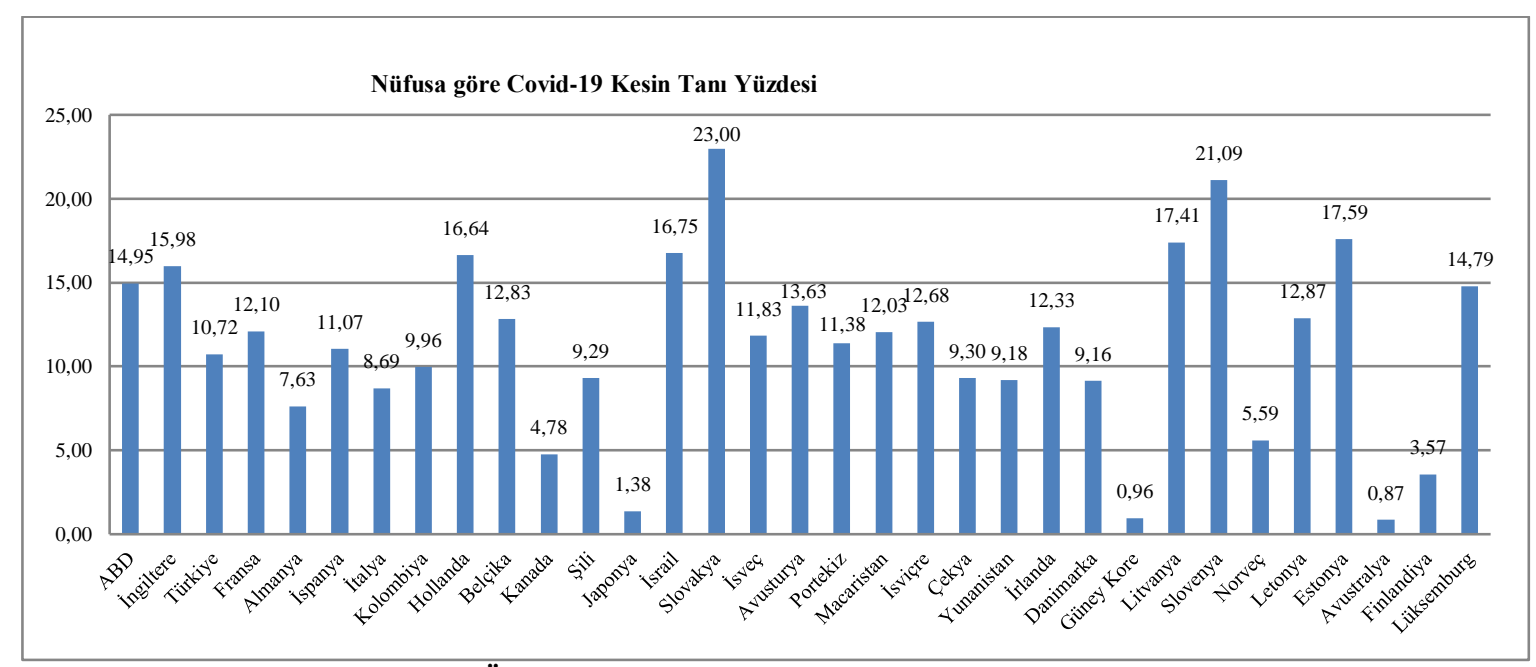

Kaynak: https://corona.cbddo.gov.tr/

Grafik 1'de, 06 Aralık 2021 tarihi itibari ile OECD ülkelerinin nüfusuna oranla Covid-19 kesin tanı yüzdesi verilmiștir. Buna göre ülke nüfuslarına oranla en fazla kesin tanı oranı Slovenya, Slovakya, Estonya, İsrail ve Hollanda'da konulmuştur. Nüfuslarına göre en az kesin tanı konulan ülkeler Avusturalya, Güney Kore, Japonya, Finlandiya ve Kanada'dır.

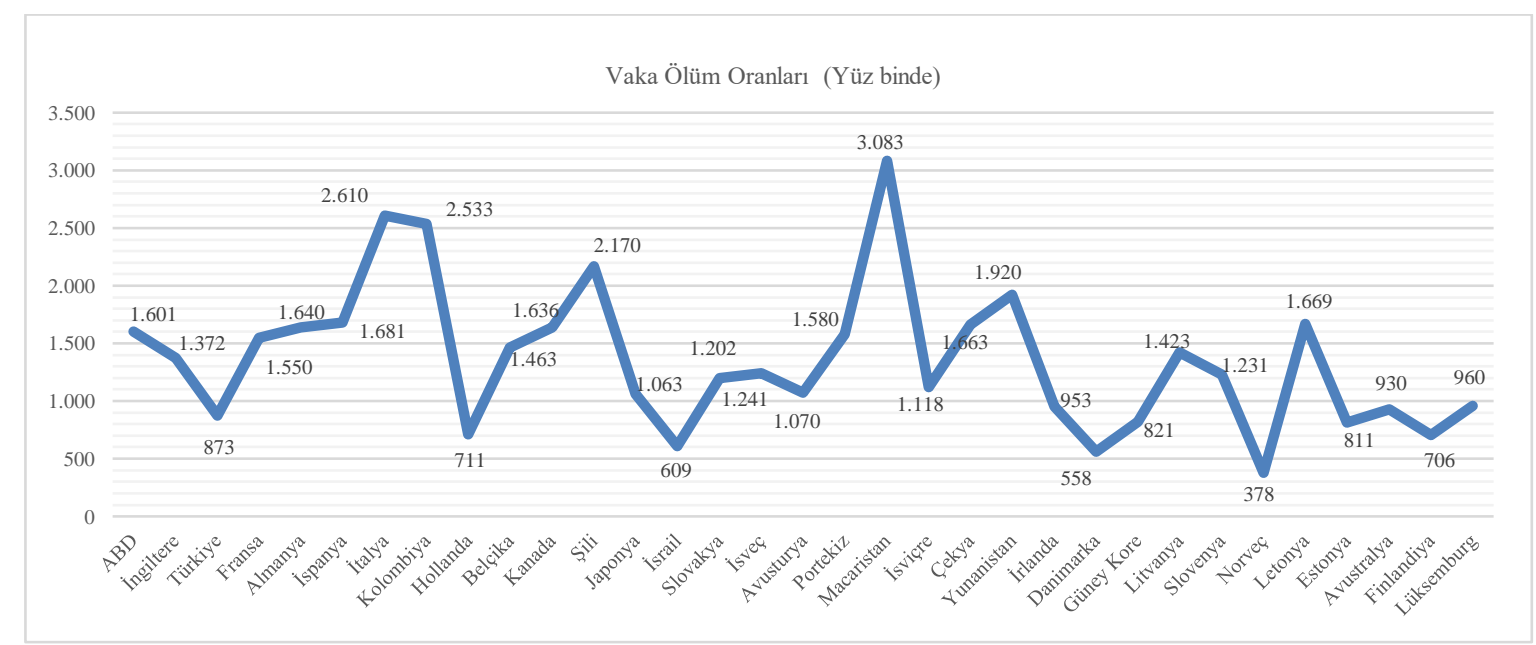

Kaynak: https://corona.cbddo.gov.tr/

Grafik.2 OECD ülkeleri Covid-19 Vaka ölüm oranları

Grafik 2'de, 06 Aralık 2021 tarihi itibari ile OECD ülkelerinde doğrulanmış kesin tanılarda meydana gelen ölümlerin oranı verilmiş̧ir. Buna göre bildirilen doğrulanmış vakalara göre en yüksek ölüm oranı sırası ile yüz binde 3.083 ile Macaristan, yüz binde 2.610 ile İtalya'da, yüz binde 2.533 ile Kolombiya'da, yüz binde 2.170 ile Şili'de ve yüz binde 1.920 ile Yunanistan'dadır. En düşük ölüm oranları ise sırası ile yüz binde 378 Norveç, 558 Danimarka, 609 İsrail, 706, Finlandiya, 711 Hollanda ve yüz binde 873 ile Türkiye'dedir. 


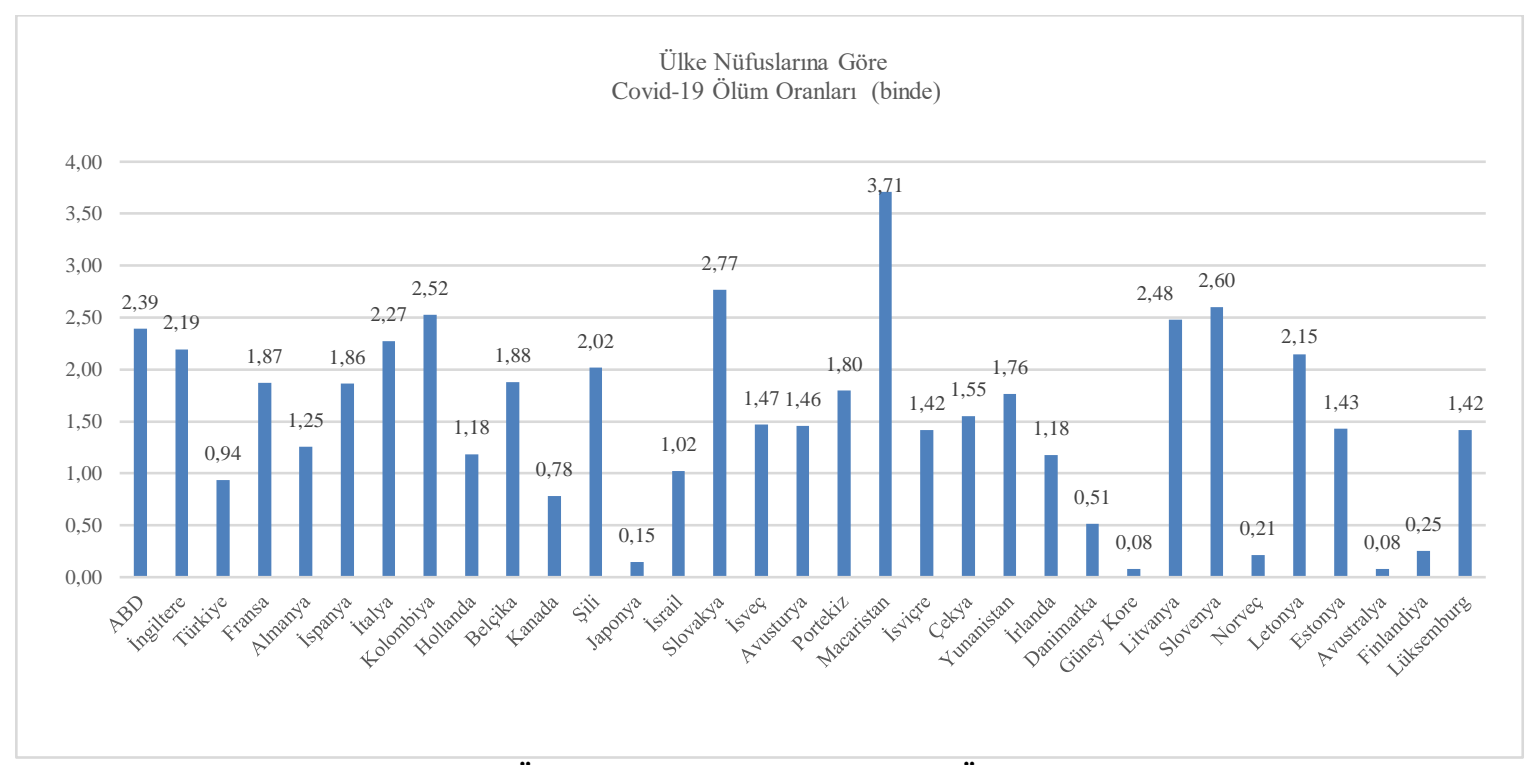

Kaynak: https://corona.cbddo.gov.tr/

Grafik 3'te, 06 Aralık 2021 tarihi itibari ile OECD ülkeleri nüfuslarına göre Covid-19'dan ölüm oranları verilmiştir. Buna göre en yüksek ölüm oranları binde 3.71 ile Macaristan, 2,60 Slovenya, 2.77 Slovakya, 2.52 Kolombiya, 2.39 ile ABD, 2.27 ile İtalya' da görülmüştür. Nüfusa göre en düşük ölümler ise Güney Kore (\%o 0.08), Avustralya (\%o 0.08), Japonya (\%o 0.15), Norveç (\%o 0.21), Finlandiya (\%o 0.25$)$, Danimarka (\%o 0.51$)$, kanada (\%o 0.78$)$ ve Türkiye'de (\%o 0.94$)$ görülmüştür.

\subsubsection{Covid-19 Așılanma İstatistikleri}

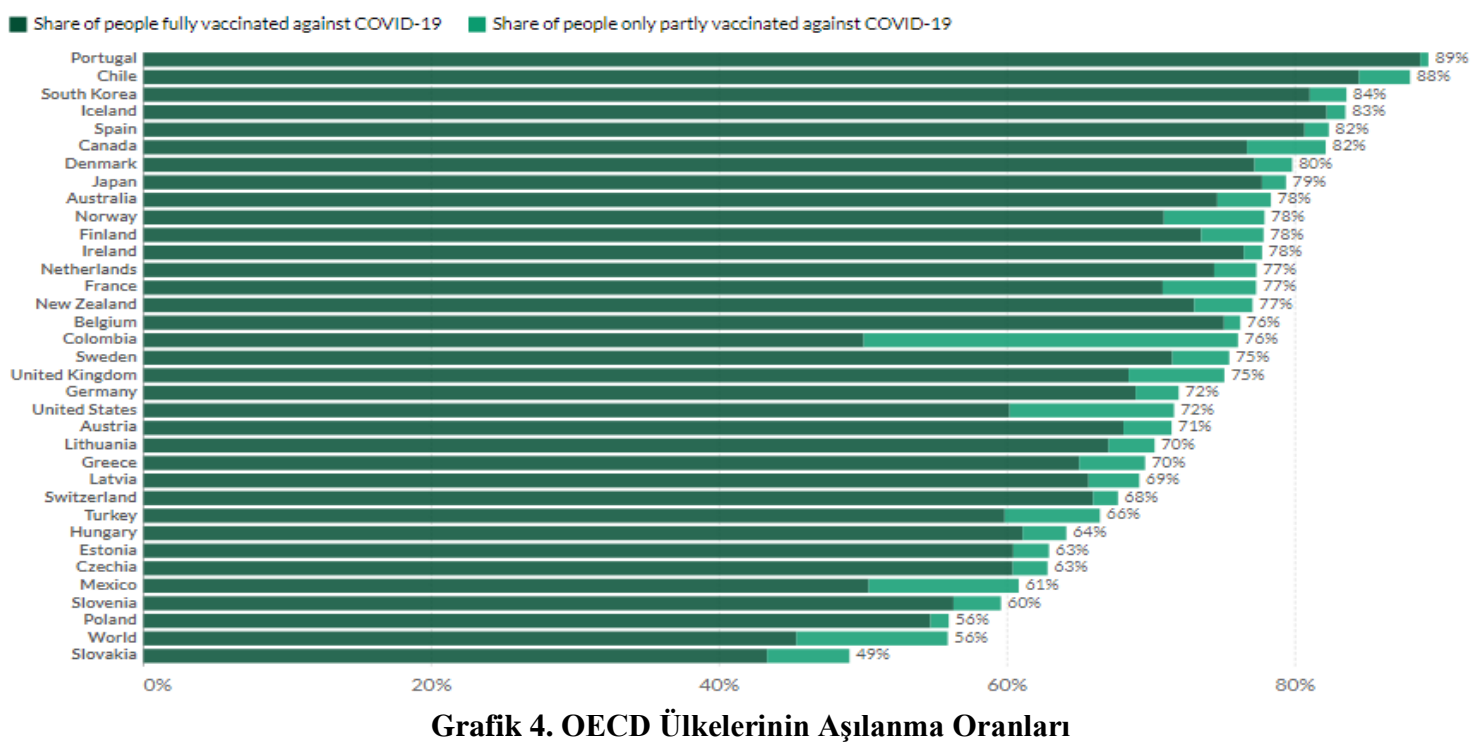

Kaynak: Our World in Data

Grafik 4'te OECD ülkelerinin tamamen veya kısmen aşılanma oranları belirtilmektedir. 10 Aralık 2021 tarihli şekle göre en fazla aşılama oranına sahip ülkeler Portekiz (\%89), Şili (\% 88) ve \%84 ile Güney Kore’dir. En az aş1lama oranına sahip ülkeler ise Slovakya (\%49), Polonya (\%56) ve \% 61 ile Meksika'dır. Türkiye ise \%66 ile OECD ülkeleri arasında alt sıralarda yer almaktadır. Ancak bu sıralamada ülkemiz nüfusunun tamamına ( 83 milyon) oranlama yapıldığından oran bu Grafikdedir. Normalde 18 yaş üstü nüfusta aşılama oranı $\% 82$ 'dir. 


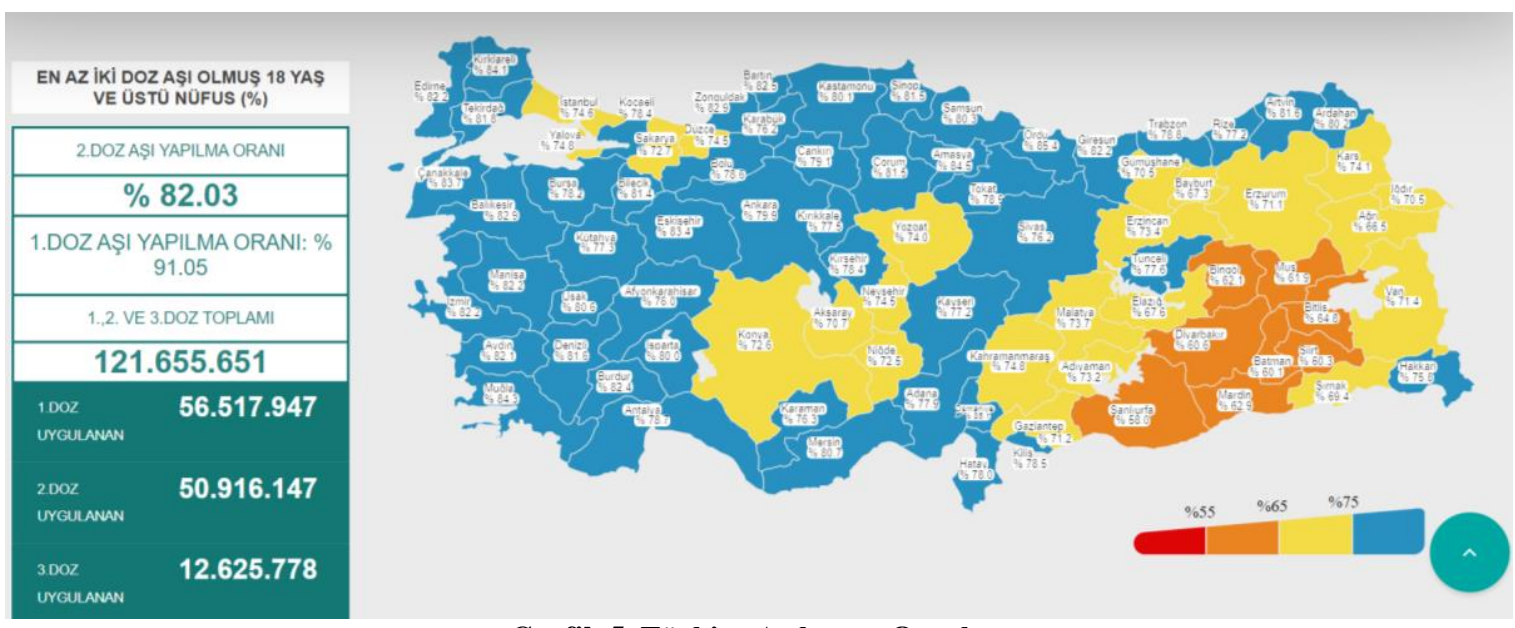

Grafik 5. Türkiye Aşılanma Oranları

Kaynak: https://covid19asi.saglik.gov.tr/

Grafik 5'te Türkiye Cumhuriyeti Sağlık Bakanlığı Covid-19 bilgi merkezince her 2 dk da bir güncellenen verilere göre en az iki doz aşı olmuş 18 yaş ve üstü nüfusu ve illere göre dağılımı göstermektedir. Türkiye'de 13 Aralık 2021 tarihi itibariyle 1 . Doz aşı yapılma oranı \%91.05, 2. Doz aşı yapılma oranı ise \%82.03'dir. 1. 2. ve 3. doz aşı toplamı 121.655.651 dir. Bu oran birçok OECD ve Avrupa ülkesine göre yüksektir. Bununla birlikte Grafik 4'teki ülkemiz sıralamasının nüfusun tümü değerlendirilerek yapılmış olduğu görülmektedir.

\subsubsection{Yatak Kapasitelerinin Karşılaştırılması}

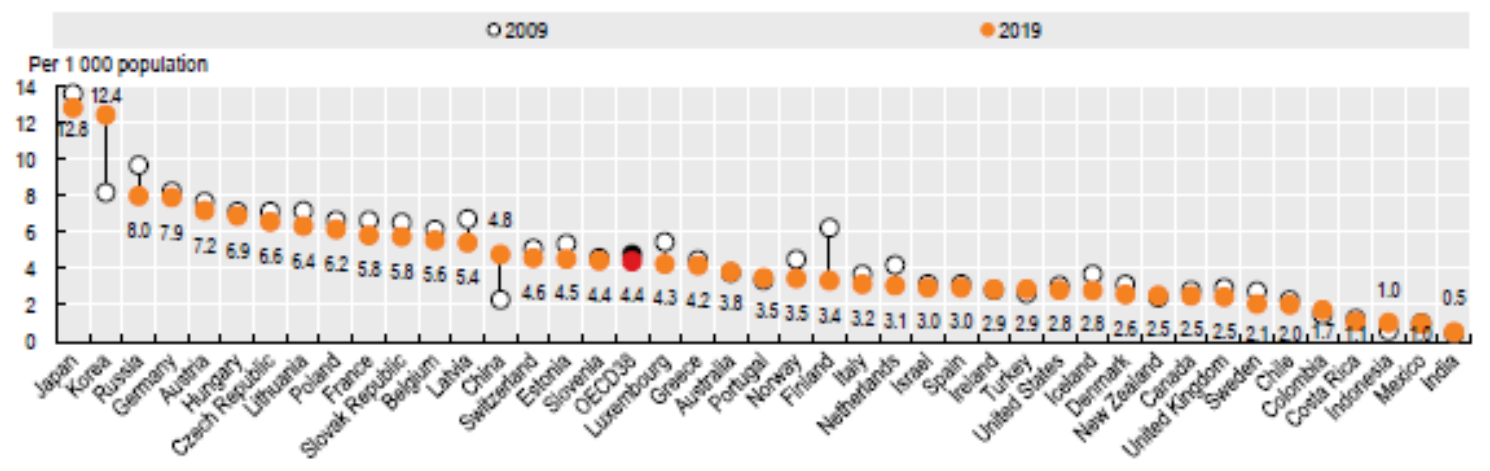

Grafik 6. 1.000 Kasi
Kaynak: OECD Sağlık İstatistikleri 2021

Grafik 6'ya göre AB, OECD ülkeleri ve diğer ülkeler arasında 1.000 kişiye düşen hastane yatağ1 sayısında en yüksek orana sahip ülkeler: Japonya, Güney Kore, Rusya ve Almanya'dır. En düşük orana sahip ülkeler ise Hindistan, Meksika, Kolombiya ve Endonezya'dır. Türkiye'de ise bin kişide kişi başına 2.9 hasta yatağı düşmektedir.

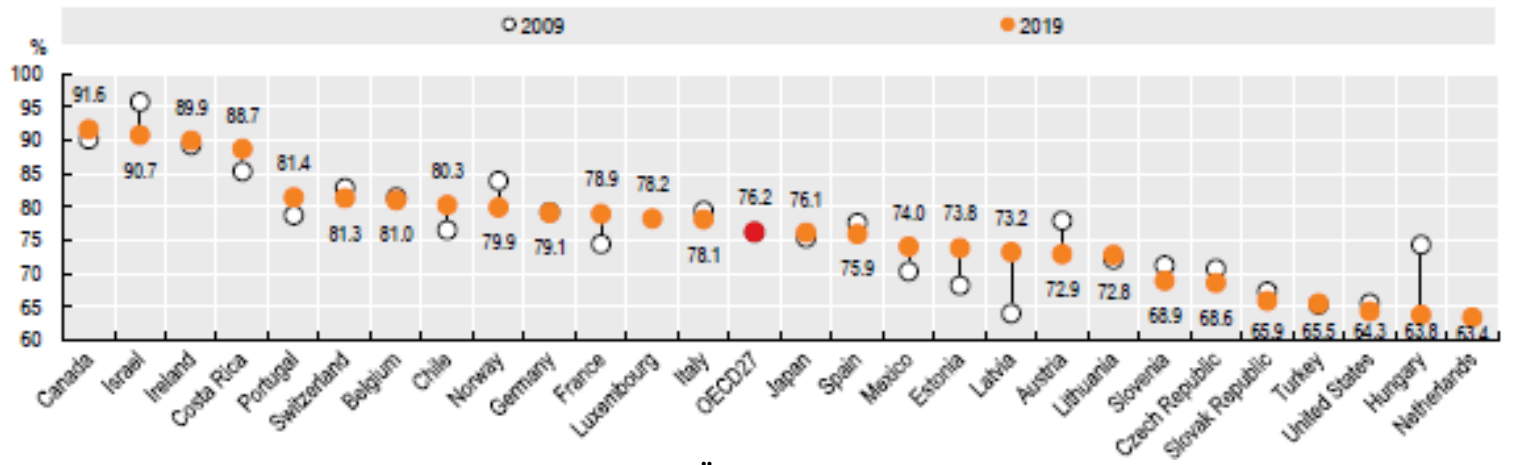

Grafik 7. OECD ve Diğer Ülkelerinin Yatak Doluluk Oranları

Kaynak: OECD Sağlık İstatistikleri 2021

Grafik 7 incelendiğinde OECD ülkelerinde ortalama yatak doluluk oranı \%76,2 iken bu oran Türkiye'de \%65,5'tir. Yatak doluluk oranı en fazla olan ülkeler; Kanada, İsrail, İrlanda, Kosta Rika ve Portekiz'dir. En düşük yatak doluluk oranına sahip ülkeler Hollanda, Macaristan, ABD ve Türkiye'dir. 


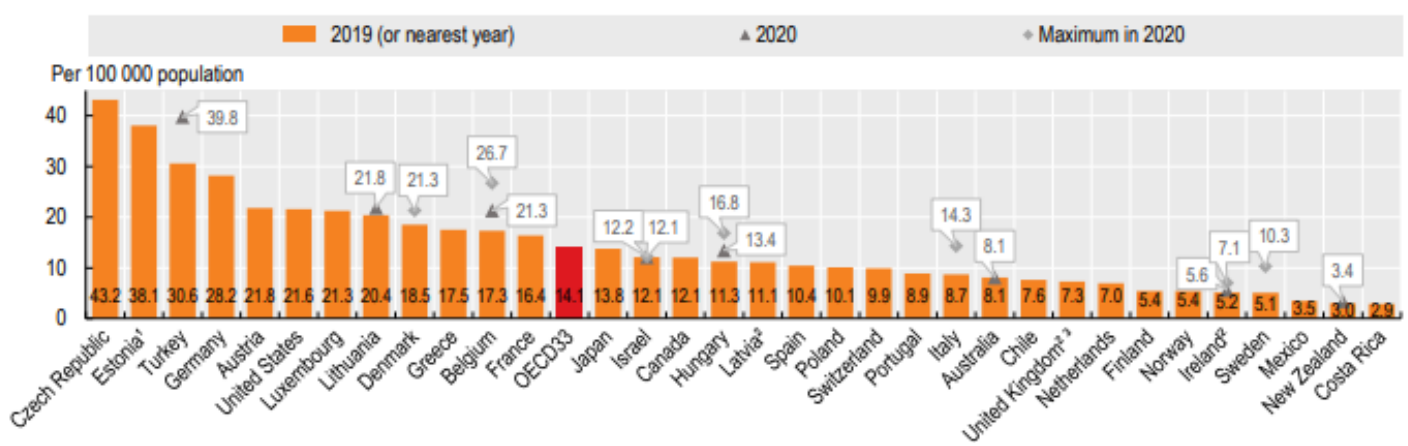

Grafik 8. 100.000 Kişiye Düşen Yoğun Bakım Yatak Sayısının Uluslararası Karşılaştırılması

Kaynak: OECD Sağlık İstatistikleri 2021

Grafik 8'de OECD ülkelerinin 2019 ve 2020 yıllarındaki 100.000 kişiye düşen yoğun bakım yatak sayısını görülmektedir. şekle göre en çok yoğun bakım yatak sayısı oranına sahip ülkeler Çekya, Türkiye ve Estonya'dır. Türkiye'yi Almanya ve Avusturya takip etmekte, en düşük orana sahip OECD ülkeleri ise, Kosta Rika, Yeni Zelanda, Meksika ve İsveç'tir. Pandemi döneminde yoğun bakım yatak sayısı önemli bir ihtiyaç olmuş olup Türkiye bu konuda yeterli sayıda yoğun bakım yatağına sahip olup, gerekli bakım ve tedavi hizmetini en şekilde yapmıştır. Bunun sonucu olarak Türkiye'de Covid-19 nedeni ile meydana gelen ölümler bir çok gelişmiş ülkeden düşük sayıdadır.

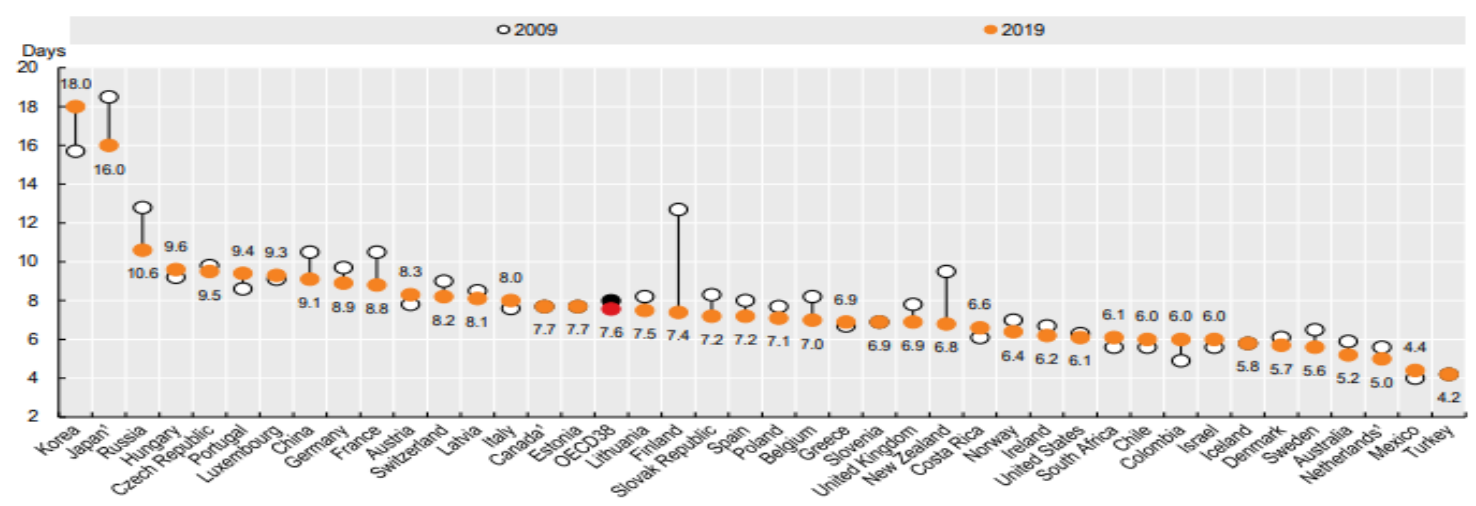

Grafik 9. Hastanede ortalama yatış süresi

Kaynak: OECD Sağlı İstatistikleri 2021

Grafik 9'da OECD ülkeleri ve diğer ülkeler arasında hastanede ortalama yatış süreleri verilmiştir. Buna göre en fazla hastanede yatma süresi Güney Kore (18 gün), Japonya (16 gün), ve Macaristan'dadır (9.6 gün). Hastanede en az yatış süresi ise Türkiye (4.2 gün), Meksika (4.4 gün), ve Hollanda'dadır (5.2 gün).

\subsubsection{Sağlık Personeli Sayılarının Karşılaştırılması}

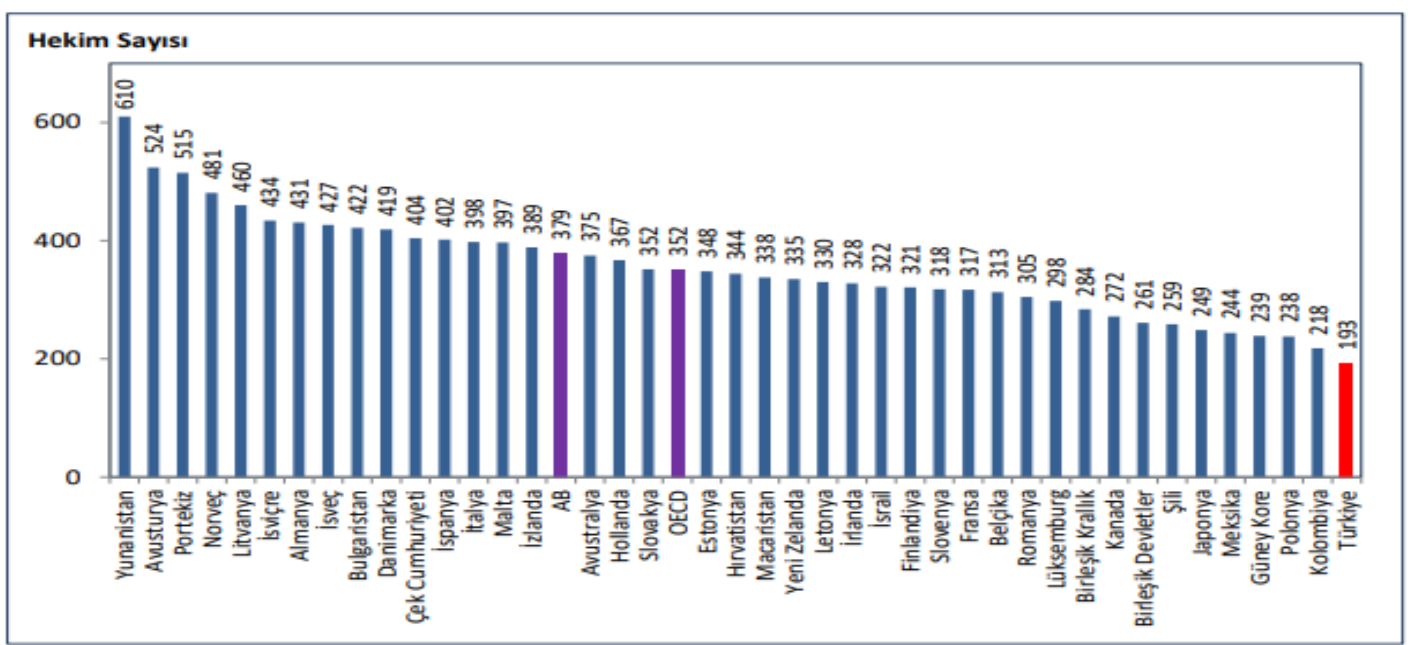

Grafik 10. 100.000 Kişiye Düşen Hekim Sayısı

Kaynak: Sağlık Bakanlı̆̆ı Sağlık İstatistikleri Yıllığı 2019. 
Grafik 10'da, OECD ülkelerinin 100.000 kişiye düşen hekim sayısını göstermektedir. Buna göre, en fazla hekim sayısına sahip ülkeler; Yunanistan, Avusturya ve Portekiz, en az hekim sayısına sahip ülkeler ise Türkiye Güney Kore ve Polonya’dır.

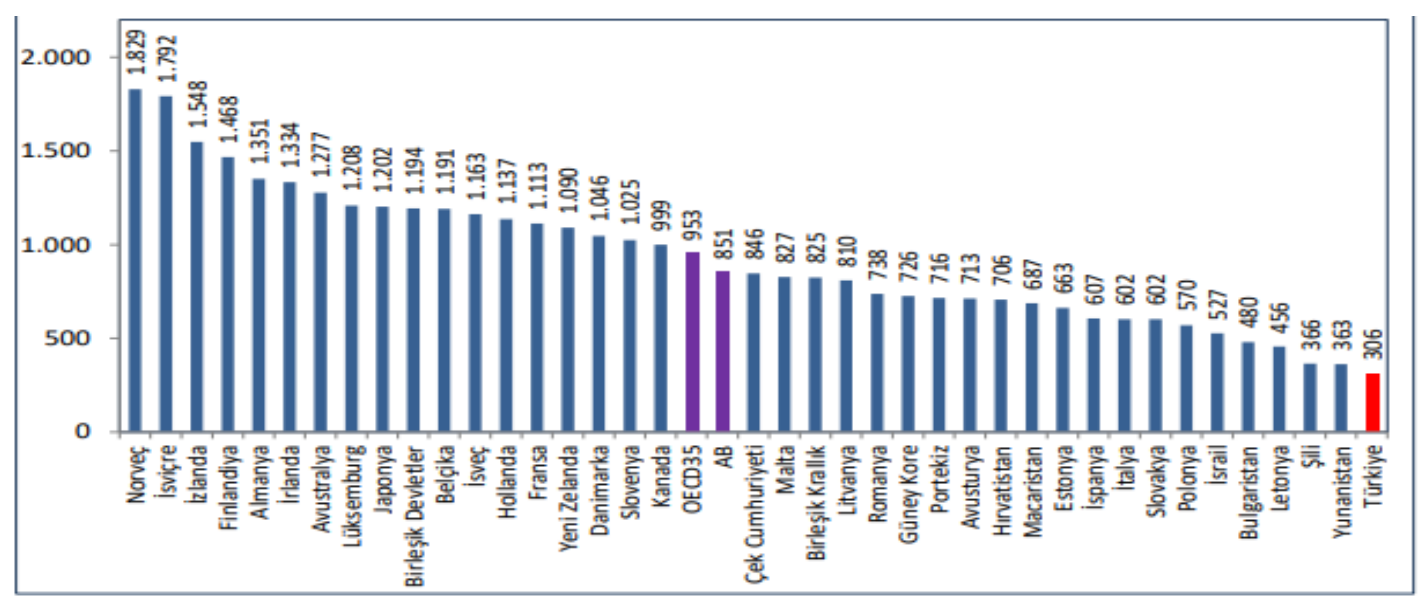

Grafik 11. 100.000 Kişi Başına Düşen Hemşire ve Ebe Sayısı

Kaynak: Sağlık Bakanlığı Sağlık İstatistikleri Yıllığı 2019.

Grafik 11 OECD ülkelerinin 100.000 kişiye düşen hemşire ve ebe sayısını göstermektedir. Şekle göre, en fazla hemşire ve ebe sayısı oranına sahip ülkeler, Norveç, İsviçre ve İzlanda, en düşük orana sahip ülkeler ise Türkiye, Yunanistan ve Şili'dir. Türkiye OECD ülkeleri arasında 1000 kişi başına düşen en düşük hekim ve hemşire sayısına sahiptir. Bu sebeple; Türkiye birçok ülkeyle kıyaslandığında nüfusa göre hekim ve hemşire sayısını artırması yararlı olacaktır.

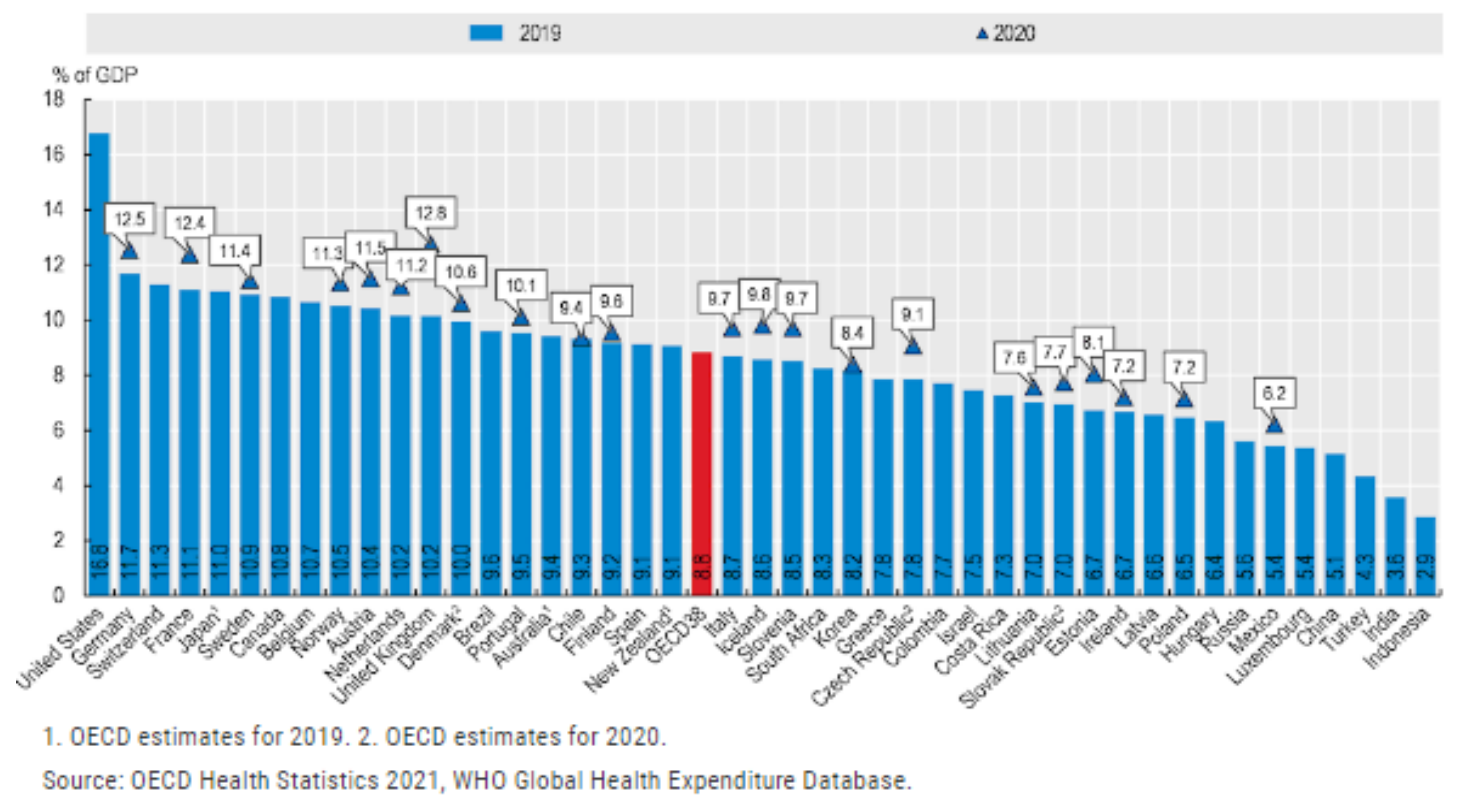

Grafik 12. Sağlık Harcamalarının Gayri Safi Hasıla İçindeki Payı

Grafik 12'de ülkelerinin gayri safi yurt içi hasılaya göre sağlık harcamaları verilmiştir. Ülkelerin sağlık harcaması dinamiklerini analiz ederken, sağlık harcamalarının GSYİH'ya oranını dikkate almak önemlidir (OECD \& AB, 2020:160). Grafiğe göre; en fazla sağlık harcaması yapan ülkeler sıralaması; ABD, Almanya, İsviçre ve Fransa'dır. Sağlığa ayrılan bütçe OECD ülkelerine oranla Türkiye'de daha düşük seviyelerdedir. OECD ortalaması \% 8.8 iken ülkemizde sağlık harcamalarının gayri safi hasılaya oranı $\% 4.3$ 'tür.

Ayrıca Türkiye OECD ülkeleri arasında kişi başı en az sağlık harcaması yapan ülkeler arasında 2. sıradadır ve ülkelerin GSYİH'dan sağlık giderleri için ayrılan pay ortalamasında \%8,8 ile düşük seviyededir. En fazla pay ayıran ülkeler; İsviçre, Fransa ve Almanya'dır (Özer ve Çetinkaya, 2020: 122).

\subsection{Tartışma}

Çalışmada OECD ülkeleri arasındaki Covid-19 verileri, aşılanma oranları, yatak doluluk ve yatak işgal oranları ve sağlık personeli sayıları karşılaştırılmıştır. 
Buna göre ülke nüfuslarına oranla Covid-19 en fazla kesin tanı (Grafik 1) Slovenya, Slovakya, Estonya, İsrail ve Hollanda'da konulmuştur. Nüfuslarına göre en az kesin tanı konulan ülkeler Avusturalya, Güney Kore, Japonya, Finlandiya ve Kanada'dır. Tanı konulma oranı bir çok faktöre bağlıdır. Görüldüğü üzere nüfusu az olan Slovenya, Slovakya, Estonya, İsrail ve Hollanda gibi ülkelerde tanı oranı nüfusa oranla yüksektir. Bu durum bu gibi ülkelerde tanı araçlarının nüfusun çoğuna ulaşılabilir olması ile açıklanabilir. Bu oran ülkemizde 10.72'dir.

Dünya Sağlık Örgütü’ne bildirilen doğrulanmış Covid-19 vakalarına göre en yüksek ölüm oranı (Grafik 2) sırası ile yüz binde 3.083 ile Macaristan, yüz binde 2.610 ile İtalya'da, yüz binde 2.533 ile Kolombiya'da, yüz binde 2.170 ile Şili'de ve yüz binde 1.920 ile Yunanistan'dadır. En düşük ölüm oranları ise sırası ile yüz binde 378 Norveç, 558 Danimarka, 609 İsrail, 706 , Finlandiya, 711 Hollanda ve yüz binde 873 ile Türkiye'dedir.

Grafik 3'te OECD ülkeleri nüfuslarına göre Covid-19'dan ölüm oranları verilmiştir. Buna göre en yüksek ölüm oranları binde 3.71 ile Macaristan, 2,60 Slovenya, 2.77 Slovakya, 2.52 Kolombiya, 2.39 ile ABD binde 2.27 ile İtalya'da görülmüştür. Nüfusa göre en düşük ölümler ise Güney Kore (\%o 0.08), Avustralya (\%o 0.08), Japonya (\%o 0.15), Norveç (\%o 0.21), Finlandiya (\%o 0.25), Danimarka (\%o 0.51), Kanada (\%o 0.78) ve Türkiye'de (\%o 0.94) görülmüştür.

Covid-19'a bağlı ölüm oranlarının düşük olduğu ülkelerde, Covid-19' karşı erken yanıt, yeterli sağlık altyapısı, korunma tedbirlerinin etkililiği, bakım ve tedavi süreçlerinin kalitesi gibi pek çok faktörün Covid-19'a bağlı ölüm oranlarının bu ülkelerde düşük olmasına etki ettiği söylenebilir. Türkiye'de Covid-19'a bağlı ölümlerin nüfusuna ve kesin tanı almış vakalara göre düşük olduğu ülkeler arasındadır. Bunda yıllardır sağlığa yapılan yatırımların etkisinin büyük olduğunu söyleyebiliriz. Son yıllarda yapılan şehir hastaneleri ve modern yoğun bakımlar, tıbbi cihaz ve donanımlar ile Covid-19'a hızla yanıt verilmiş olması ve tedavi süreçlerinin başarısının göstergesi olarak Covid-19'a bağlı ölümler düşük sayıdadır.

En fazla aşılama oranına sahip ülkeler Portekiz (\%89), Şili (\% 88) ve \%84 ile Güney Kore’dir. En az aşılama oranına sahip ülkeler ise Slovakya (\%49), Polonya (\%56) ve \% 61 ile Meksika'dır. Türkiyede18 yaş üstü aşılama oranı \% 82’dir (Grafik 5).

AB, OECD ülkeleri ve diğer ülkeler arasında 1.000 kişiye düşen hastane yatağı sayısında en yüksek orana sahip ülkeler: Japonya, Güney Kore, Rusya ve Almanya'dır. En düşük orana sahip ülkeler ise Hindistan, Meksika, Kolombiya ve Endonezya'dır. Türkiye'de ise bin kişide kişi başına 2.9 hasta yatağı düşmektedir (Grafik 6). OECD ülkelerinde ortalama yatak doluluk oranı $\% 76,2$ iken bu oran Türkiye'de \%65,5'tir. En düşük yatak doluluk oranına sahip ülkeler Hollanda, Macaristan, ABD ve Türkiye' dir. Ülkemiz diğer ülkelere göre yatak sayısı bakımından OECD ülke ortalamasının altında olmasına rağmen yatak doluluk oranları OECD ortalamasından ve çoğu ülkeden düşük durumdadır.

OECD ülkeleri arasında en çok yoğun bakım yatak sayısı oranına sahip ülkeler Çekya, Türkiye ve Estonya'dır. Türkiye'yi Almanya ve Avusturya takip etmekte, en düşük orana sahip OECD ülkeleri ise, Yeni Zelanda, Meksika ve İsveç’tir (Grafik 8). Covid-19 başlangıcında birçok ülkede hastalar için yoğun bakım yeri ve tıbbi cihaz artan talebe bağlı olarak bulunamamıştır. Türkiye hem yoğun bakım kapasitesi hem de hastane ve tıbbi malzeme kapasitesi bakımından kendi kendine yetebilen ülkelerin başında yer almıştır. OECD yoğun bakım ortalaması yüz bin kişide 14.1 iken Türkiye'de bu oran 2020 yılında 39.8 olmuştur.

Grafik 9'da OECD ülkeleri ve diğer ülkeler arasında hastanede ortalama yatış süreleri verilmiştir. Buna göre en fazla hastanede yatma süresi ortalama Güney Kore (18 gün), Japonya (16 gün), ve Macaristan'dadır (9.6 gün). Hastanede en az yatış süresi ise Türkiye (4.2 gün), Meksika (4.4 gün), ve Hollanda'da (5.2 gün)'dür. OECD ülkeleri arasında en az hastanede kalış süresi Türkiye'dedir. Bu durumun ülkenin nüfus yapısı, tedavi ve bakım süreçlerinin kalitesi, sağlık altyapısının hızlı cevap verebilirliği gibi pek çok faktörle açıklamak mümkündür. Bu konunun nedenlerine yönelik detaylı araştırma yapılması gerekmektedir. Ülkemiz açısından bu oldukça olumlu bir durumdur. Sağlık harcamalarının yükünün az olmasının bir nedeni bu veri ile ilişkilendirilebilir.

OECD ülkelerinin 100.000 kişiye düşen hekim sayısına bakıldığında (Grafik 10) en fazla hekim sayısına sahip ülkeler; Yunanistan, Avusturya ve Portekiz, en az hekim sayısına sahip ülkeler ise Türkiye, Güney Kore ve Polonya'dır. Bununla birlikte yatak doluluk oranları en düşük ve Covid-19'dan ölümlerin az olduğu ülkeler arasında yine Türkiye ve Güney Kore yer almaktadır. Doktor sayısının fazla olduğu Yunanistan ve Portekiz'de ise Covid-19 nedeni ile ölümler daha yüksek düzeydedir.

Yüz bin kişi başına en fazla hemşire oranına sahip ülkeler (Grafik 11), Norveç, İsviçre ve İzlanda, en düşük orana sahip ülkeler ise Türkiye, Yunanistan ve Şili'dir. Türkiye OECD ülkeleri arasında 1000 kişi başına düşen en düşük hekim ve hemşire sayısına sahiptir. Bu sebeple; Türkiye birçok ülkeyle kıyaslandığında nüfusa göre hekim ve hemşire sayısını artırması yararlı olacaktır.

Ülkelerinin gayri safi yurt içi hasılaya göre sağlık harcamalarına (Grafik 12) baktığımızda, en fazla sağlı harcaması yapan ülkeler sıralaması; ABD, Almanya, İsviçre ve Fransa'dır. Sağlığa ayrılan bütçe OECD ülkelerine oranla Türkiye'de daha düşük seviyelerdedir. Sağlık harcamalarının gayri safi yurt içi hasılaya oranı OECD ortalaması \% 8.8 iken ülkemizde sağlık harcamalarının gayri safi hasılaya oranı \% 4.3 'tür. Aslında bu olumlu bir göstergedir. Ülkemizde hem yatak doluluk oranı hem de ortalama yatış süresi diğer ülkelerden düşük durumdadır. Bu durumun nüfus yaş aralığı yönünden de incelenmesi gerekmektedir. Ülkemiz kısmen daha genç nüfusa sahiptir. Bununla birlikte sağlık hizmetlerine erişim daha kolay durumdadır. Ülkemizin sağlık harcamalarının düşük düzeyde olması yukarıda belirtilen ve daha başka birçok faktörle açıklanabilir. 


\section{Sonuc}

OECD ülkelerinin sağlık istatistikleri, Covid-19 verileri, yatak kapasitesi, aşılanma oranları, sağlık personeli sayıları ve sağlık harcamaları yönünden karşılaştırılmıştır. Açıklanan kesin vakalarda Covid-19'dan en yüksek ölüm oranı sırası Macaristan, İtalya, Kolombiya, Şili ve Yunanistan'da meydana gelmiştir. En düşük ölüm oranları ise Norveç, Danimarka, İsrail, Finlandiya, Hollanda ve Türkiye'dedir.

En fazla aşılama oranına sahip ülkeler Portekiz, Şili ve ve Güney Kore'dir. En az aşılama oranına sahip ülkeler ise Slovakya, Polonya ve Meksika'dır. Ülkelerin yoğun bakım kapasiteleri Covid-19 hastalığında önemli ihtiyaç haline gelmiştir. Yoğun bakım kapasitesi ve tıbbi cihaz kapasitesi yetersiz olan çoğu ülke Covid-19'un başlangıcında hastalara hızlı müdahalede bulunamadı. Bu durum Covid-19'dan ölümlerin ilk dönemlerde daha hızlı ve yüksek olmasına neden oldu.

OECD ülkeleri arasında en çok yoğun bakım yatak sayısı oranına sahip ülkeler Çekya, Türkiye ve Estonya'dır. Türkiye'yi Almanya ve Avusturya takip etmekte, en düşük orana sahip OECD ülkeleri ise, Yeni Zelanda, Meksika ve İsveç’tir. Türkiye yoğun bakım kapasitesi olarak en iyi ülkelerden birisidir.

Türkiye sağlık personeli sayısı bakımından OECD ülkeleri arasında düşük durumdadır. Sağlık personeli sayısının artırılması gerekmektedir. Genel olarak ülkemiz sağlık istatistiklerine bakıldığında diğer ülkelerle Covid-19 verileri (ölüm oranları, yatak doluluk oranları vb) karşılaştırıldığında ülkemizin Covid-19 ile mücadelede başarılı olduğunu söyleyebiliriz. Aşılamanın artması ile Covid-19'a bağlı ölümlerin tüm dünyada daha da azalacağı beklenmektedir.

\section{Referanslar}

Akarsu vd., B. (2021). While Studies on Covid-19 Vaccine is Ongoing, the Public's Thoughts and Attitudes to the Future Covid19 Vaccine. The International Journal of Clinical Practice, 1-10.

Budak, F., \& Korkmaz, Ş. (2020). COVID-19 pandemi sürecine yönelik genel bir değerlendirme: Türkiye örneği. Sosyal Araştırmalar ve Yönetim Dergisi, (1), 62-79.

Chakravorty vd., I. (2020). An Online Survey of Healthcare Professionals in the COVID-19 Pandemic in the UK: Perceptions of Risk Factors. Journal of Health Policy \& Opinions, 1-16.

Cheng, K., Hing Lam, T., \& Leung, C. (2020). Wearing Face Masks in the Community During the COVID-19 Pandemic: Altruism and Solidarity. The Lancet, 1-2.

Coustasse vd., A. (2020). Letter to the Editor: COVID-19 and Vaccine Hesitancy. Journal of Ambulatory Care Management, 71-75.

Du, Q., Zhang, D., Hu, W., Li, X., Xia, Q., Wen, T., \& Jia, H. (2021). Nosocomial infection of COVID-19: A new challenge for healthcare professionals. International Journal of Molecular Medicine, 47(4), 1-1.

Elgar, K., Lopert, L., Carey, E., \& Wenzl, M. (2021). Coronavirus (COVID-19)vaccines for developing countries: An equal shot at recovery. Tackling Coronavirus(Covid-19)- Browse OECD Contributions, 1-22.

Erkekoğlu, P., Erdemli-Köse, S. B., Balcı, A., \& Yirün, A. (2020). Aşı Kararsızlığı ve COVID-19'un Etkileri. Literatür Eczacilık Bilimleri Dergisi , 208-220.

Eroğlu, G. (2020). Covid-19'la Mücadele Sürecinde Türkiye'deki Yardım Hizmetleri ve Uygulamalarına Genel Bir Bakış. Şehir ve Medeniyet, 527-703.

Erol, S. I. (2020). Basic Provisions of International Labor Norms Intended for the Covid-19 Outbreak: Japan, China, USA \& Turkey Samples. Journal of Economics, Business \& Political Studies, 142-159. 34.

Eser, B., Özer, M., \& Çiçek, T. E. (2021). Türkiye'deki COVID-19 Salgını Yönetimi ve Sonuçları. Şehir Sağlığı Dergisi, 26-

Farboodi, M., Jarosch, G., \& Shimer, R. (2020). Internal and External Effects of Social Distancing in a Pandemic. NBER Working Paper Series, 1-65.

Galván-Tejada, C. (2020). Persistence of COVID-19 Symptoms after Recovery in Mexican Population. International Journal of Environmental Research and Public Health, 1-12.

Gooch, A. (2020). Co-operating on Vaccines: What We Must Do Next. Covid-19 ile Mücadele. OECD: The Forum Network. 
Gölbaşı, S. D., \& Metintaş, S. (2020). Dünya Sağlık Örgütü'nün Covid-19 Pandemisinde Küresel Sürveyans Çalışmaları. ESTÜDAM Halk Sağlığı Dergisi, 184-213.

Halpin vd., S. (2021). Postdischarge Symptoms and Rehabilitation Needs in Survivors of COVID 19 Infection: A Cross Sectional Evaluation. Journal of Medical Virology,93, 1013-1022.

Iserson, K. (2020). Healthcare Ethics During a Pandemic. Western Journal of Emergency Medicine, 1-7. 171 .

İmga, O., \& Ayhan, U. (2020). Covid-19 Salgını ve Sonrası: Toplum, Devlet ve Küresel Sistem. Polis Akademisi Yayınları, 1-

Karmakar, M., Lantz, P., \& Tipirneni, R. (2021). Association of Social and Demographic Factors With COVID-19 Incidence and Death Rates in the US. JAMA Network Open, Vol.4, No.1, 1-12.

Keskin, B. Y. (2020). Almanya Corona virüsü salgınıyla nasıl mücadele ediyor? Erişim Adresi: https://www.milliyet.com.tr/almanya-corona-virusu-salginiyla-nasil-mucadele-ediyor--molatik-14718/:

Kozlovskaya vd., L. (2021). Long-term Humoral Immunogenicity, Safety and protective Efficacy of Inactivated Vaccine Against COVID-19 (CoviVac) in Preclinical Studies. Emerging Microbes \& Infections, 1790-1806.

Kumar, R., Singh, V., Mohanty, A., Bahurupi, Y., \& Kumar-Gupta, P. (2021). Corona Health Care Warriors in India: Knowledge, Attitude, and Practices During COVID 19 oOutbreak. Journal of Education and Health Promotion,Vol.10, DOI:10.4103/jehp.jehp_524_20,1-10.

Machingaidze, S., \& Wiysonge, C. (2021). Understanding COVID-19 Vaccine Hesitancy. news \& views, 1338-1344.

Munis, R., \& Aydın, M. S. (2021). Pandemi ile Mücadelede Maliye Politikası Uygulamaları: Türkiye ve G7 Ülkeleri Karşılaştırılması. Anadolu Univercity Journal of Faculty og Economics, 55-81.

OECD, \& AB. (2020). State of Health in the EU Cycle. Health At A Glance: Europe 2020 C OECD/European Union, 1-233.

OECD, (2021). OECD health Glance, Erişim Adresi: https://www.oecd.org/health/health-at-a-glance/ https://www.oecdilibrary.org/sites/ae3016b9-en/1/3/8/index.html?itemId=/content/publication/ae3016b9-

en\&_csp_=ca413da5d44587bc56446341952c275e\&itemIGO=oecd\&itemContentType=book

Özer, A., \& Çetinkaya, F. (2020). Sağlık Hizmetleri ve Postpandemik Dönemde Sağlık Hizmetlerinin Dönüşümü. Türkiye Bilimler Akademisi, 113-130. 77.

Quer, G. (2021). Wearable Sensor Data and Self-Reported Symptoms for COVID-19 Detection. Nature Medicine, vol.27, 73-

Rab vd., S. (2020). Face Masks are New Normal After COVID-19 Pandemic. Diabetes \& Metabolic Syndrome: Clinical Research \& Reviews, 1617-1619.

Shepard vd., J. (2021). The Prevalence of Covid-19 in Healthcare Personnel in an Adult and Pediatric Academic Medical Center. American Journal of Infection Control, 49, 542-546.

T.C. Sağlık Bakanlığı (2021) Covid-19 ile Mücadele ve Covıd-19 Aşısı Bilgilendirme Platformu Erişim Adresi: https://covid19asi.saglik.gov.tr/

Tengilimoğlu, D., Zekioğlu, A., Tosun, N., Işık, O., \& Tengilimoğlu, O. (2021). Impacts of COVID-19 pandemic period on depression, anxiety and stress levels of the healthcare employees in Turkey. Legal Medicine, 48, 101811.

Timmis, K., \& Brüssow, H. (2020). The COVID-19 Pandemic: Some Lessons Learned about Crisis Preparedness and Management, and the Need for International Benchmarking to Reduce Deficits. Environmental Microbiology, 1986-1996.

Troiano, G., \& Nardi, A. (2021). Vaccine Hesitancy in the Era of COVID-19. Public Health, 245-251.

Watkins, J. (2020). Preventing a Covid-19 Pandemic - We need to think beyond containment. thebmj, BMJ 2020;368:m810 doi: 10.1136/bmj.m810 (Published 28 February 2020) 1-2.

Yalçın-Balçık, P., \& Demir, H. (2021). Aşı Karşıtlı̆̆ı ve Ekonomisi. Hacettepe Sağlık İdaresi Dergisi, Vol.24, No.2, $375-398$. 
Yan vd., Y. (2021). Risk Compensation and Face Mask Mandates During the COVID 19 Pandemic. Scientific Reports, 1-11.

Yıldızoğlu, E. (2020). Koronavirüs: ABD'de salgın krizi nasıl büyüdü? Erişim Adresi: https://www.bbc.com/turkce/haberlerdunya-52200598

Yiğit, A. (2020). OECD Ülkelerinin Covid 19 Pandemisi ile Mücadele Performansı: Kesitsel Bir Araştırma. Journal of Current Researches on Social Sciences, 400-416.

Yorulmaz, M., Kıraç, R., \& Aydoğdu, A. (2021). Covid-19'a Karşı Alınan Ekonomik Önlemlerin Büyüklüklerinin Belirlenmesi: Amerika, Almanya, İngiltere, İtalya ve Türkiye Örneği. International Anatolia Academic Online Journal, 161-175. 